\title{
How an Exporter Faces the Challenges From the Maker
}

\author{
Michael Kon, Tzu-wen Sung \\ Aletheia University, Taiwan \\ Long-sheng Kung \\ National Taiwan University, Taiwan
}

\begin{abstract}
Both academic and industrial circles always think that exporters basically have no potentials to compete with their factories (suppliers) on overseas markets. However, this may not be the case. The objective of this paper is to study whether exporters can compete with factories in the international market and further have more advantages. In order to achieve this goal, this paper uses the research methods of Document Analysis, Qualitative Analysis, and SWOT Analysis to evaluate the collected information and explore the opportunity for exporters to survive. As a result, this paper finds that when a factory wants to deal directly with a foreign importer, the exporter can take some effective measures to face the challenges from the factory. For examples, the exporter may use an exclusive agency contract to prevent the factory from dealing directly with the foreign importer; the exporter can apply some special payment terms to induce close cooperation between the factory and the importer; the exporter can discontinue providing the factory with key parts when the factory has direct deal with the importer.
\end{abstract}

Keywords: exclusive agency contract, payment terms, SWOT

\section{Introduction}

\section{General Background Information}

In terms of an exporter, the relevant information about importers and factories are the important commercial secrets and assets for it. How can an exporter compete with the supplier (factory) on foreign markets? One of the important reasons is that the exporter can carefully keep the secrets (Kon, 1999). Generally speaking, an exporter's profit is based on the difference between the supplier's quotation price and exporter's selling price. When this difference is greater, it seems inevitable that the supplier and importer are more likely to directly do business without the involvement of the exporter. Then the exporter will face a crisis of losing all possible business opportunities. Therefore, in order not to let both of the importer and supplier directly deal with each other, the exporter should not only clearly understand their integrities and enlarge its own supply potentials on different items, but also try to reach "Exclusive Agency Agreements" with them and promote its own R\&D abilities.

Usually, the role of an exporter is that it purchases products from a factory and then adds its expected

Michael Kon, Dr., Associate Professor, Dept. of International Trade, Aletheia University, Taiwan.

Tzu-wen Sung, Dr., Assistant Professor, Dept. of International Trade, Aletheia University, Taiwan.

Long-sheng Kung, Ph.D., student, Institute of National Development, National Taiwan University, Taiwan. 
profits to the products and sells them to the importer. Sometimes, in order to obtain higher profits, factories or importers may want to get rid of the exporter and trade directly (Karunaratna, Johnson, \& Rao, 2010). Under this kind of pressure, the exporter must be careful to avoid the possibility that factory and importer can know each other from catalogues, name cards, operation manuals, etc. Therefore, the focus of this paper is to discuss how the exporter can use professional skills, rigorous contract, and its own strengths to make itself play an irreplaceable role in the process of trade; consequently, the supplier and the importer cannot do business directly.

In order to avoid misunderstanding of some essential terms, this paper defines them as follows:

a. Exporter: It refers to a seller who is a middleman (export trading company) and specializes in the export trade.

b. Factory (Supplier): It refers to a production maker who can supply and sell its products to overseas markets through exporters. ${ }^{1}$

c. Importer: It means a vendee (buyer) who always imports something from overseas markets.

d. Import agent: It means a middleman who always represents importers to buy something from overseas markets. $^{2}$

\section{Literature Review}

In order to save costs, factories often sell their products to the international market through exporters. Once the factory observes that it is more advantageous to trade directly with the importer, conflicts between the exporter and the factory may occur. Therefore, exporters should be alert at all times and do not accidentally leak any information about the importer to the factory. According to Kon (1999), exporters should be particularly careful about the information leak of shipping documents, so that factories are not able to get it. If the payment term is a transferrable Letter of Credit $(\mathrm{L} / \mathrm{C})$, the exporter may transfer the $\mathrm{L} / \mathrm{C}$ to the factory and will definitely leak the importer's information specified in the L/C to the factory. Therefore, if the exporter is unable to pay a very high deposit to the factory while placing an order with the factory, the exporter can ask the importer immediately to issue a Back-to-Back L/C in favor of itself on receipt of an order placed by the importer. Receiving the Back-to-Back L/C, the exporter can ask its negotiating bank to open a Local L/C based on the Back-to-Back L/C in favor of the factory. In this Local $\mathrm{L} / \mathrm{C}$, there is no information about the importer.

Although most people believe that when the exporter and the factory compete with each other in the international market, the factory often has an advantage. But in fact, it is not necessarily so. Both sides can build their own core competencies based on their advantages. Kon (2009) states that although the factory has an advantage of controlling delivery time and price, the exporter can still force factories to maintain close cooperation with it. Coman and Ronen (2009) point out that a company should turn its strengths into core competencies without exposing the core issues.

To impede the desperate competition situation that the factory wants to deal directly with the importer, the exporter should reach an exclusive agency contract with the factory before their mutual cooperation. Also, the

\footnotetext{
${ }^{1}$ MBAlib.com (2018). Factory [online]. Available at: http://wiki.mbalib.com/zh-tw/Factory [Accessed February 25, 2018].

2 MBAlib.com (2018). Export Agent [online]. Available at: http://wiki.mbalib.com/zh-tw/Import_agent [Accessed February 25, 2018].
} 
penalty should be clearly specified in the contract. Kon (1999) conclude that in order to effectively obstruct direct transactions between the importer and the factory, the exporter should specify the clear penalties in the exclusive agency contract. Matouschek and Ramezzana (2007) and Marin and Sicotte (2003) also show that it is optimal for agents to adopt an exclusive agency contract, and that an exclusive contract can increase the seller's profits and market power. Wong and Popp (2018) stress that the stability of a sole agency agreement can encourage the emergence of innovations in marketing, selling, and product development.

In order to solve the conflicts between exporters and factories caused by the intensive competition in foreign markets, the best way is of course to get resolution through negotiation. In the process of negotiation, for the purpose of achieving a satisfactory result in a friendly atmosphere, both parties should understand each other's position and adopt the best negotiation mode before negotiation. Liu and Sharma (2011) find that channel members should take into account two vital outcomes during the negotiation process: substantive benefits and relationship outcome. Hawes and Fleming (2014) emphasize that they use the concept of adaptive negotiation to help negotiators select their styles.

If the exporter wants to prevent betrayal from happening, the exporter can use financing methods to make the factory and the importer maintain closer partnerships with it. Kon (2005) notes that if the exporter is willing to export its products to the importer with more lenient payment terms (Documents Against Payment-D/P, Document Against Acceptance-D/A, and Open Account-O/A), it is obvious that the importer is with strong support and good financing from the exporter. In other words, if the exporter can place an order with the factory by the payment term of Cash With Order or Cash in Advance, it also means a full support and goodwill from the exporter. Kon (2005) also explains that L/C is often regarded as a fair and safe payment term for both sellers and buyers. What kinds of payment terms are to be taken by exporters and importers usually depends on whether the current international market becomes a seller's market or a buyer's market. In the case of the seller's market, the seller can of course claim the importer to use the payment term of Cash With Order or Cash in Advance; in the buyer's market, the exporter may have to follow the buyer's request for the payment terms of $\mathrm{D} / \mathrm{P}, \mathrm{D} / \mathrm{A}$, or $\mathrm{O} / \mathrm{A}$.

In the paper, to evaluate the collected information and to explore the opportunity for exporters to survive, the following methods will be applied. They are: the research methods of Document Analysis, Qualitative Analysis, and SWOT Analysis. Furthermore, our practical experience in international trade will be utilized to find survival and development opportunities for exporters.

\section{Research Purpose and Methodology}

The purpose of this research is trying to explore if the exporter can find its strength and opportunity and use them to compete with the factory in the overseas markets. This paper also tries to find whether the exporter has the survival possibility through applying professional skills and capacities and signing contracts with the importer and factory respectively. Regarding research methods, this paper will apply the methods of Document Analysis, Qualitative Analysis, and SWOT Analysis. Furthermore, this paper will also refer to our past practical experience to analyze how the exporter can fight against the factory and the importer.

\section{Overview}

This paper is divided into five parts: the first part briefly introduces the background, research purpose, and 
method; the second part uses SWOT Analysis to evaluate the advantages and disadvantages of the exporter and factory; the third part describes how the exporter faces challenges from the factory and the importer respectively to maintain its business opportunities; the fourth part discusses how the exporter uses stringent contract and its own strengths to fight with the factory; the fifth part puts forward the author's opinions and draw a conclusion.

\section{The Role of an Exporter in the Indirect Trade}

The main functions of exporters in the international trade are that the exporter can use its intimate international trade knowledge and innovation ability to run international trade. The normal operation procedure of indirect trade can be specified as follows: The exporter buys some products from factories, plus its profits, and then sells them to other buyers in foreign countries.

\section{The Definition of "Indirect Trade"}

Roughly speaking, the trade between the buyer and the seller being through some intermediate persons is called "Indirect Trade". The exporter always plays a role of middleman employing its expertise to buy and sell some products. ${ }^{3}$

Usually, the "Indirect Trade" includes two modes (Figures 1 and 2). The first mode shows that the factory can sell its goods to overseas markets or areas through local exporters (refer to Figure 1), and the second mode shows that the exporter can sell its goods to overseas markets or areas through its overseas purchasing agents in the importer's country (refer to Figure 2). The "Indirect Trade” emphasized in this paper refers to the former one. As shown in Figure 1, the factory ships its products to the destination country through an exporter.

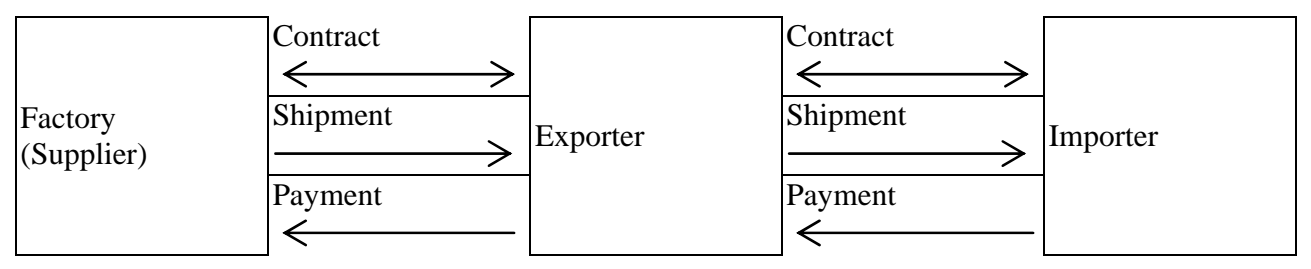

Figure 1. Indirect trade.

Another mode of indirect trade is shown as in Figure 2, which shows that the factory ships its products to the overseas importer through purchasing agents.

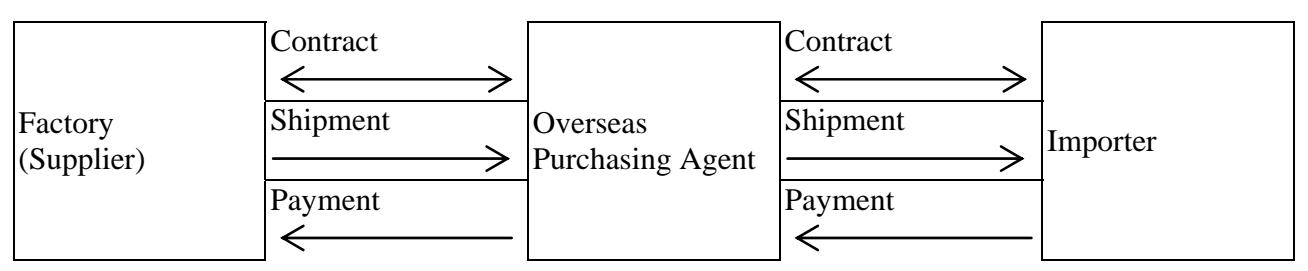

Figure 2. Indirect trade.

Indeed, being an exporter, its survival and competitive pressure come from factories, foreign buyers, and other hard situations (Manvi \& Venkataram, 2015). No matter what pressure comes, effective marketing strategy and innovation ability will be the survival elements of an exporter. It means that when the world

\footnotetext{
${ }^{3}$ It means that the exporter purchases some products from factories and then sells them to foreign importers.
} 
economic growth and factory's profits are both quite good, the factory can satisfactorily and peacefully run its overseas markets through exporters (Kon, 1997). But when either the world economic growth or the factory's profit is not good, the factory will automatically consider running its overseas markets directly by itself without using the connection of the exporter. Of course, sometimes the factory may be just in the passive situation as the importer secures the factory's information through the internet and expresses that it wishes to directly transact with the factory no more through the exporter. ${ }^{4}$

No matter where the threat comes from, there is no doubt that export trading companies are facing the critical survival point. If the exporter wants to survive under the threats from the factory and the importer, it must take some effective measures to negotiate or fight with them.

\section{The SWOT Analysis of an Exporter}

The export price quoted by an exporter is based upon the quotation of the factory. It also means that the exporter usually adds some commission to the quotation of the factory and then quotes this final price to overseas potential importers. In the normal situation, the price quoted by an exporter will be higher than that quoted by the factory. Therefore, most people think that the competitiveness of an exporter is inferior to that of a factory. But according to a precise SWOT Analysis (Shinno, Yoshioka, Marpaung, \& Hachiga, 2007), the actual status is probably not like this.

The strengths of an exporter. Usually, in comparison with the factory, an exporter has the following strengths (Kon, 1999):

a. An exporter does not need large capital investments;

b. An exporter usually can do product diversification to avoid business risks;

c. An exporter can be more flexible to adjust the scale of its business;

d. An exporter is easier to obtain goods from different suppliers, but a factory is difficult to obtain goods from its competitors (Coman \& Ronen, 2009);

e. An exporter can more easily transmit the learned lessons to its new employees;

f. An exporter can evaluate and control its export cost easier.

g. An exporter doesn't need huge financial supports;

h. An exporter can collect a large amount of orders to press factories to grant it a big discount (Takahashi \& Matsuo, 2012).

The weaknesses of an exporter. Nevertheless, in comparison with the factory, the exporter also has the following weaknesses:

a. The export prices of an exporter are always subject to the factory;

b. An exporter's quotation is usually higher than the factory's, so the exporter cannot easily compete with the factory;

c. An exporter cannot easily secure its orders from local customers;

d. An exporter cannot easily build a production line;

e. An exporter cannot control the product quality and delivery time;

${ }^{4}$ Of course, sometimes the factory may be just in the passive situation as the importer secures the factory's information through the internet and expresses that it wishes to directly transact with the factory no more through the exporter. 
f. An exporter is likely to lose its customers if the factory involves in the direct deal with the importer.

The opportunities of an exporter. Even if the exporter is under much pressure from the factory and the importer, it can still develop some business opportunities:

a. An exporter can easily offer its creative ideas to ask different factories to arrange production line for it (Lee \& Oh, 2012);

b. An exporter can apply international certificates or patents for some key parts, and use these key parts to control factories;

c. An exporter can elaborate with different factories, therefore it has greater supply capacity;

d. An exporter usually has more professional knowledge and higher innovative abilities (Álvarez, Faruq, \& Lopez, 2012);

e. The organization costs of an exporter are usually lower than those of a factory;

f. An exporter can more easily transfer its order to other suppliers;

g. An exporter can always transfer customer's complaints and claims to the factory, but factories can just accept the complaints;

h. An exporter can more easily get the orders from foreign importers because it possesses the strengths of professional and communication skills;

i. An exporter can supply some certified or patented parts to the factory for production, and these parts are not permitted to make products for other firms;

j. An exporter won't suffer environmental and ecological protests from the social movement groups.

The threats to an exporter. Even if the exporter has some advantages to face the challenges from the factory, it still will encounter some unavoidable threats:

a. An exporter often faces the threat that the factory will raise the quotation cost;

b. An exporter often faces the risk of foreign exchange appreciation;

c. An exporter always faces the threat that the factory wants to directly deal with the importer;

d. An exporter usually cannot solve the questions raised by the importer about qualities, and those questions have to be dealt with by the factory;

e. An exporter faces many international risk variables (such as war, strike, or typhoon);

f. Some foreign importers will use the information from the internet to directly contact factories and place orders.

\section{Brief Summary}

In terms of the perspectives of the factory, indirect trade results from the fact that the factory in the exporting country is not familiar with the existing sales channels in the importing country. Under this kind of situation, indirect trade can help the factory save its marketing costs and lower its cost through the larger scale of production. Usually the exporter quotes its prices to overseas importers according to its factory's quotation. It seems that the exporter is always under the disadvantageous situation. But from the WOT Analysis, we can know that the exporter still has some effective advantageous strengths and opportunities. If the exporter can grasp the strengths and opportunities, it still has much room for its survival and development. 


\section{An Exporter's Success in Conducting Negotiation}

An exporter may lose the business chance in the export process. For example, the exporter could accidentally leak out the factory's brand or data in relative documents. Moreover, both the importer and the maker can find each other from the internet and then get rid of the exporter and directly deal with each other (Kon, 2009). Facing these possible hard situations, the exporter should launch its negotiation with the importer and the factory respectively (Pelecki, 2016), and then try to use some effective measures to make both sides have scruples.

\section{Negotiating With Domestic Factories}

The main reason that the factory is likely to directly do business with the importer is to increase its profits. ${ }^{5}$ Having the factory dispeling the idea, the exporter should negotiate with the factory and have the factory realize that its direct transaction with the importer will make itself earn fewer profits and suffer more harm (Liu \& Sharma, 2011).

Persuading the factory with emotion. The exporter should tell the factory that both of them have cooperated with each other for a long time, and there is no need to hurt each other. At the same time, the exporter can guarantee that it definitely will not place its orders with other factories (Wong \& Popp, 2018).

Convincing people by sound reasoning. The exporter can tell the factory that it has done business with foreign importers for many years and had very good business relations; therefore, it is not possible for the factory to secure orders from the foreign importer. And the exporter can tell the factory that if it receives orders from the importer, the orders will be definitely placed with the factory, rather than with other factories.

Bringing to the law. The exporter can directly tell the production factory that it has signed an "Exclusive Agency Agreement” with the importer, so the two ends will abide by the provisions of the contract (Cai \& Drake, 2016). Then, the exporter can guarantee that it will definitely get the orders and place them with the factory.

Forcing with power. The exporter can tell the factory that if the factory insists on directly dealing with the importer, its future orders will turn to other factories. As far as this is concerned, the factory will have more concerns and doesn't persist in acting willfully (Kon, 2006).

Playing the exporter's trump card. If the exporter cannot retrieve the situation that the factory wants to directly deal business with the importer, the exporter can play its trump card. It means that the exporter does not add any commission to the quoted price by the factory or even drops $1 \%$ and directly quotes to the importer. ${ }^{6}$ Finally the exporter can get the order placed by the foreign importer, and the factory loses the chance. For example, from Figure 3, you can finally find that the exporter received the order at the price USD99/set and it probably can make a counter offer at USD89/set to the factory. Under this kind of situation, the factory has two choices: a. It accepts the counter offer at the price USD89/set, which is lower than the original offer at USD100/set; b. It just declines the counter offer from the exporter and abandons the business chance with the exporter. As to the exporter, it can cooperate with other suppliers for future orders.

\footnotetext{
${ }^{5}$ Obviously, there is no ground for an exporter to oppose the action of the factory.

6 Thus, the factory's quotation directly offered to the importer obviously will be higher than the exporter's because the factory wants to make more profits.
} 


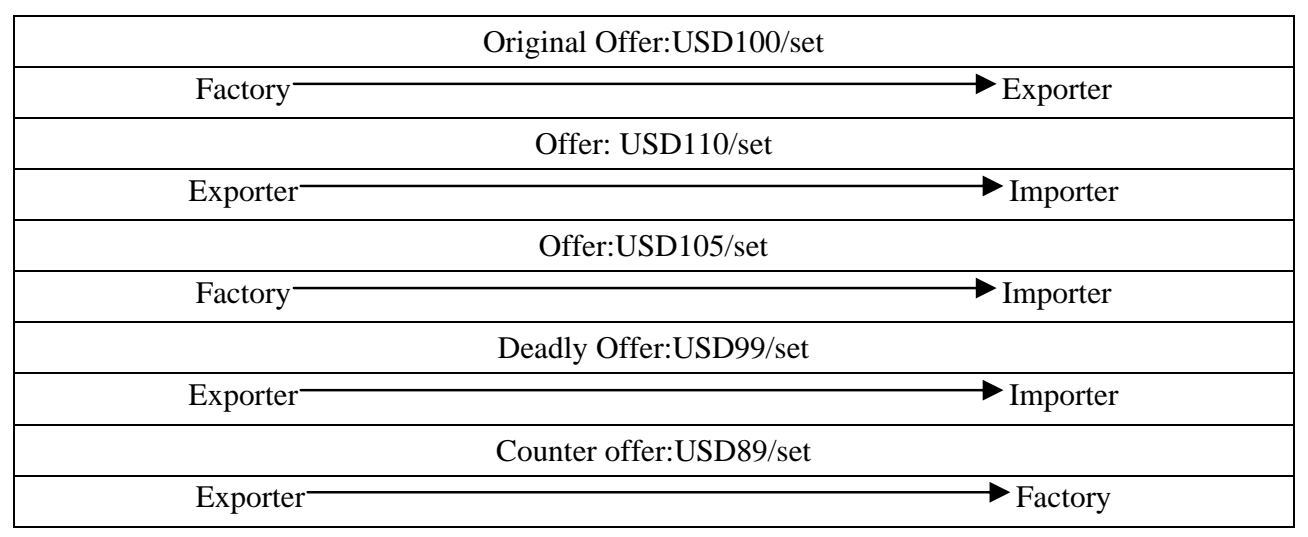

Figure 3. Bidding process.

\section{Negotiating With the Foreign Importer}

The main purpose of directly dealing with the factory by the foreign importer is that the importer thinks it can make more profits. Therefore, if the exporter wants to impede the direct deal between the factory and the importer, it must make the importer clearly realize the exporter's strengths (Weinstein \& Still, 2010).

Emphasizing its better supply capacity. Foreign importers usually import a variety of products, but the factory can only offer very few products it manufactures. Therefore, the exporter can offer better services owing to the fact that the exporter usually can offer different kinds of products. Thus, the exporter can tell the importer that if the importer insists on directly dealing with the factory, it will not be able to provide other products and services to the importer. ${ }^{7}$

Quality control. If the foreign importer's order is placed through the exporter, the exporter can easily visit the factory to supervise the quality control and shipping schedule (Manrai \& Ajay, 2010). Therefore, the order placed by the importer can access to more secure quality control, and the importer is not worth making a small profit to hurt the long-term cooperative partners.

The exporter can accept tiny orders from the importer. Usually the factory is not easy establishing a production line for a small order placed by overseas importers. But the exporter can collect many small orders from overseas markets and then place the total order with the factory.

More supplier sources. Usually the factory probably will decline a tiny order and cannot execute a huge order from the importer in a short time. However, the exporter is more familiar to the local markets and factories, it can accept either small or large orders. Also, the exporter can collect small orders placed by different oversea importers to place total order with one factory. At the same time, the exporter can easily divide its big order into small ones and place them with different suppliers to match the urgent demand from the importer.

\footnotetext{
${ }^{7}$ This pressure will force the importer to have no choice but to give up directly dealing with the factory.
} 


\section{Brief Summary}

Of course, exporters should deem the information related to the foreign importers as trade secrets. Therefore, in any case, they should do their best to prevent both the importer and the production factory from communicating with each other. But currently the internet is so advanced that every importer can easily find the supply sources because most factories have some relevant information on the internet. If both the importer and the factory can successfully get in touch with each other through internet, the exporter can take the following measures to face the factory's challenge: a. Strengthening the long-term business relationship and sentiments with the factory; b. Guaranteeing its loyalty to the factory; c. Bringing to the law; d. Forcing the factory with power and playing the exporter's trump card. The exporter can also take some actions to face the importer: emphasizing its better supply capacity, helping the importer control its order quality, being able to accept any small orders, enlarging to offer services to more product fields.

\section{The Use of Contracts (Agreements)}

Generally speaking, the importer and the domestic factory are likely to have an idea that if they can directly trade with each other, both of them can make more profits respectively. ${ }^{8}$ Therefore, in addition to the aforementioned methods, the exporter can also take advantage of a detailed contract to deter their direct cooperation. There is no doubt that the exporter can also enhance its power in hand to press the factory and the importer. As a consequence, the factory and the importer will be reluctant to do any business directly with each other.

\section{To Add a Protection Clause to the Sales Contract}

In most cases the international market is the so-called buyer's market. The exporter should sign a sales contract with the factory, including a protection clause, to constrain the factory's action that may damage the interests of the exporter (Wilson, 2013). In other words, the exporter can carefully plan the contents of a sales contract to protect its interests. It means that in addition to the common terms in the sales contract, the exporter can emphasize the following clauses and specify the penalties for the breach of the contract:

a. No permission for showing special characters and signs in the shipment. The factory is not permitted to show the information of its brand, trademarks, name cards, catalogues, price lists, envelopes, letter paper, or any other materials with the factory's title and address in the shipment (Bigsten et al., 2007). If the factory violates this article, it will be fined with 10 times of the total order amount. ${ }^{9}$

b. No permission of direct deals. The factory is not permitted to directly deal with the importer unless the exporter agrees to this kind of deal (Hawes \& Fleming, 2014). If the factory breaches this clause, it will be fined with 10 times of the transaction amount for the exporter.

c. Pay commission on direct deal. Even the factory is consented to directly transact with the importer, the factory must pay some commission for each deal. The main reason that the exporter requires the defensive articles in the business contract is to prevent the factory and the importer from dealing directly. Also, in order to strengthen the deterrent effects, the exporter especially stipulates the penalty in the contract ( $\mathrm{Li}$, Su, \& Lam,

\footnotetext{
${ }^{8}$ So long as they have this kind of idea, it is always a threat to the exporter.

${ }^{9}$ In order to increase the pressure on the factory, the exporter can claim that the fine must be paid in one month after the exporter puts it to the proof.
} 
2009). For the purpose of saving time for the possible legal process, it is better for the exporter to have the contract notarized in the court.

\section{Signing an "Exclusive Agreements" and Expanding the Exporter's Advantages}

The purpose of signing an "Exclusive Agreement" between the exporter and the factory or between the exporter and the importer is mainly to prevent the production factory from dealing directly with the importer (Chen, 2013). As for expanding the advantages of the exporter itself, the main intention is to encourage exporters to develop its strengths so that the factory and the importer do not want and dare not trade with each other directly (Matouschek \& Ramezzana, 2007).

Signing an "Exclusive Agreement". The exporter can sign an "Exclusive Export Agency Agreement" with the domestic production factory and sign an "Exclusive Buying Agency Agreement" with the foreign importer (Hemingway, 2008). Because the contracts do prohibit the direct transaction between the factory and the importer, the exporter can be safe and doesn't worry that it will lose the business chance. ${ }^{10}$

The reasons that an exporter wants to sign an "Exclusive Export Agency Agreement" with the factory are as follows: (a) If the exporter can reach an "Exclusive Export Agency Agreement” with the importer, there is no need to worry about the fact that the factory will directly contact the importer for business because the factory is not permitted to directly ship its products to the overseas importer; (b) If the exporter can reach an "Exclusive Export Agency Agreement” with the factory, it can use the exclusive right to occupy the target market more easily in a relatively short time; c. Because the exporter obtains the exclusive right to market the factory's products in the authorized territory, it can make more profits.

The reasons that a factory is willing to authorize an exporter to develop the overseas markets are as follows: (a) The factory is usually short of overseas business experience and manpower; it can use the exporter's experience to fast enter overseas markets (Daniels, 2016); (b) The factory wants to save its developing cost and use the existing channels to quickly develop the overseas markets; (c) The factory can make more profits through mass production (Marín \& Sicotte, 2003).

The reasons that the exporter requires "Exclusive Buying Agency Agreement" signed with the importer are as follows: (a) As the exporter obtains the rights of agent, the importer is not allowed to directly buy the products from the factory. Therefore, the exporter doesn't worry about losing any business chances with the importer; (b) Because the exporter can keep more stable order quantity, it can negotiate with the factory on quantity and loyalty discounts; (c) As the exporter can receive regular orders from the importer, it can save many development costs; (d) The exporter can take the chance of stable operation to promote $R \& D$ and innovation abilities.

As for the importer, the reasons that it is willing to authorize the right of exclusive buying agent to the exporter are as follows: (a) The importer doesn't need to spend a lot of time and money finding the suppliers of goods; (b) The importer can set its mind at rest because the exporter can represent it to inspect the goods to be

\footnotetext{
${ }^{10}$ In other words, the exporter can mark up some profits on the goods bought from the factory and then sell them to the foreign importer.
} 
shipped; (c) The exporter can be on behalf of the importer to take care of the production line and delivery date of the factory; (d) The importer's loyalty to the exporter can be used as a bargaining chip in price reduction.

On the basis of above-mentioned various beneficial reasons, exporter may be easily reaching agreements with both the importer and the factory.

Expanding the exporters' advantages. Enterprises seek their maximum profits are regarded as unalterable principles. Therefore, even if the exporter reaches a lot of "Exclusive Agency Agreements" with importers and factories to restrict them to directly transact with each other, it can still be possibly breached by importers and factories. Hence the best way for an exporter to prevent importer and factory from directly dealing with each other is to promote its strengths and make importers and factories realize that if they directly deal with each other, they will be more harmed than be benefited. ${ }^{11}$

\section{How to face the challenges from factories.}

a. Making factories be subjected to exporters. Exporter can actually use their own R\&D capabilities to file patent and quality certificate application for the key components. Therefore, in the future, the factory can't use the components to produce its products without the agreement of exporters. ${ }^{12}$

b. Establishing a production line. The ability to establish a production line is a very strong pressure to the factory. The ability will let the factory fully understand that if the factory violates the "Exclusive Export Agency Agreement” to directly deal with the importer, the exporter can easily establish a production line to compete with it. Under this kind of circumstance, the factory scarcely dare breach the contract.

c. Saving for a rainy day. Exporter usually should have the ability to explore other supply sources. If someday the factories do not want to work together with the exporter or direct transact with the importer, the exporter has the ability to face the predicament. It also means that if the factory violates the agreement, the exporter can shift to cooperate with other suppliers.

d. Strong financial status. Sometimes because the factory invests much on the production equipment or has much inventory, its capital turnover is negatively influenced. Hence, if the exporter can take the chance of granting the factory some loose payment terms, such as Cash With Order (CWO) and Cash In Advance (CIA), the factory will likely keep a good and close business relationship with the exporter and won't break the agreement (Turguttopbas, 2013).

e. Professional knowledge and innovation ability. The exporter can take the opportunity of enhancing their quality on business communication, international trade law expertise to more easily secure orders from importers. Meanwhile, exporters should unceasingly advance their international professional knowledge and promote their innovation ability. Doing so can strengthen the standing of exporter and can also provide supports to the factory. Under these two kinds of conditions, exporters can not only place order with factories, but also put forward suggestions on the technology. Thus, the factory mostly relies on the exporter, so it won't abandon the exporter.

\section{How to face the challenges from importers.}

\footnotetext{
${ }^{11}$ Under such circumstances, both exporters and factories don't want to and daren't deal directly with each other.

12 Accordingly, even the factory wants to directly deal with the importer, after detailed, careful consideration, it will probably get rid of the ideas.
} 
a. Highlighting the potential threats to the importer. The importer often worries that the exporter will probably sell products to its local competitors that will affect the importer's survival and development. Therefore, if the exporter can either express or imply that it has the ability to use the marketing channels to sell products to the importer's competitors, the importer will also have scruples.

b. Granting the import favorable terms of payment. Usually after the importer receives the goods, it will immediately sell part of the goods to wholesalers or distributors, but it often receives the payment several months later and consequently faces serious capital turnover. Furthermore, sometimes the inventory accumulation will also cause cash flow problems. In this case, if the exporter can give the importer loose and preferential terms of payment, e.g., "Collection” or “O/A", the importer will likely maintain long-term business relationship with the exporter (Kon, Kung, \& Sung, 2018).

c. Promoting the exporter's supply capacities. Most importers usually adopt strategy of diversification to increase their profits and decrease business risks. In this case, if the importer imports all the needed products through different suppliers, definitely it will increase its operating costs and reduce operating efficiency (Luzzini \& Ronchi, 2016). In this context, if the exporter can offer a variety of products with full supply capacity to the importer, the importer definitely will not shift its orders to the factory.

d. Accepting small orders. Because the exporter is a middleman, it usually collects big or small orders from all over the world and then merges these orders and places them with the factory. After the process of order consolidation by the exporter, it can be easier for the order quantity to reach the minimum number of procuring requirements of the factory. ${ }^{13}$ In this regard, the importer should strengthen and pay attention to the partnership with the exporter, and the importer dare not directly do any business with the factory.

e. Helping quality control for the orders placed by the importer. The production factory definitely should be responsible for the quality control of importer's orders, but the quality and delivery negligence are usually inevitable. Therefore, an exporter can pay much attention to the delivery time and strengthen the quality inspection for the importer. Obviously, this kind of role can give much help to the importer and impede it to directly deal with the factory.

f. Offering more competitive price. Exporter's customers are usually from all over the world, so the exporter can more easily accumulate orders to a great extent, and therefore the exporter can negotiate quantity and loyalty discounts with the factory. After securing these discounts, the exporter may share these profits with the importer. Hence, as long as the importer can enjoy more profits through the deal with the exporter, the importer will be more likely to maintain cooperative relations with the exporter.

\section{Brief Summary}

The exporter wants to prevent factories and importers from directly transacting with each other; the exporter can use relevant contracts and penalties to restrict production factories and importers to contact each other. In this case, both of them dare not breach the relevant articles specified in the contracts and regulations. For examples, the factory is not permitted to do the following: putting catalogues, name cards, quotation sheets with the shipped products. In addition to contracts, the exporter can also take active measures to make the

\footnotetext{
${ }^{13}$ It also means that if the importer directly places a small order with the factory, it may be declined by the factory.
} 
production factory give up contacting the importer. These measures include: adding some protection clause to a sales contract, signing an "Exclusive Export Agency Agreement” with the importer to expand its competitive strengths.

\section{Conclusion}

No matter what academia or practical circle is working for international trade, most people think that the exporter will be at a disadvantage if it competes for international markets with a production factory. But the paper illustrates that it is not necessarily so. In fact, there are four possible results while exporters compete with factories on the international market: win-win, win-lose, lose-win, and lose-lose. First, in terms of the win-win situation, both of them can focus on international marketing and production respectively and share the common profits. Second, in the case of the win-lose situation, if the factory wants to directly deal business with the importer, the exporter can add no commission to the quoted price by the factory or even drop $1 \%$ and directly quote to the importer. Therefore, the factory's quotation directly offered to the importer obviously will be higher than the exporter's. Finally the exporter can win the order placed by the foreign importer and place it with another supplier who can provide the products with the same quality and even lower prices. Or the exporter can still place this order with the old supplier at a very low price. Third, as for the lose-win situation, according to this paper, it will not happen because the exporter will not let the factory win even if the exporter cannot win. Forth, as far as the lose-lose is concerned, the exporter may quote a very low price to the importer to successfully secure the order and place it with a new factory at a non-profitable price.

Therefore, in face of the threats from the importer and the production factory, the exporter can make skillful negotiation and sign a rigorous business contract with importers and factories to resolve the threats. Apart from these, the exporter can also take the following aggressive approaches to enhance its own strengths: (1) The exporter should build a database of factories and importers to imply the factory and the importer that it has the abilities to cooperate with other factories and importers if they break their promises. (2) The exporter can affix their own trademarks or brands on the products themselves and should apply registration as soon as possible in the destination country. In the context of these situations, even if the factory wants to directly deal with the importer, the result of sales will not be good. (3) The exporter can employ key parts to apply for patent or certification. In the future, therefore, if the production factory wants to buy the key parts for their production line, the factory will be subject to the exporter. (4) The exporter can accumulate small orders to a bigger one and then place it with the factory to obtain quantity and loyalty discounts. After that, the exporter can share these profits with the importer. (5) The exporter can allow preferential payment terms, such as CWO or CIA, to the factory. Also the exporter can agree with D/P or D/A payment term to the importer. (6) The exporter should expand its supply capacities to offer various products demanded by the importer. Under this kind of situation, the importer will be likely to rely on the exporter and dare not abandon the partnership. (7) The exporter should accept small orders placed by the importer and inspect the products seriously before shipment. (8) The exporter can try to strengthen the relationship with the factory and the importer by establishing joint ventures. (9) The exporter can provide the factory and the importer with high and fast efficient services. 


\section{References}

Álvarez, R., Faruq, H., \& Lopez, A. (2012). Is previous export experience important for new exports? The Journal of Development Studies, 49(3), 426-441.

Bigsten, A., Collier P., Dercon, S., Fafchamps, M., Gauthier, B., Gunning, J. W., Oduro, A., Oostendorp, R., Patillo, C., Soderbom, M., Teal, F., \& Albert, Z. (2007). Contract flexibility and dispute resolution in African manufacturing. The Journal of Development Studies, 36(4), 1-37.

Cai, A., \& Drake, E. (2016). The business of business negotiation: Intercultural perspectives. Annals of the International Communication Association, 21(1), 153-190.

Chen, C. (2013). International commercial agreements. Taipei: San Min Book.

Coman, A., \& Ronen, B. (2009). Focused SWOT: Diagnosing critical strengths and weaknesses. International Journal of Production Research, 47(20), 5677-5689.

Daniels, W. (2016). Export of services of servicing exports? Geografiska Annaler: Series B, Human Geography, 82(1), 1-15.

Hawes, M., \& Fleming, E. (2014). Recognizing distributive or integrative negotiation opportunities in marketing channels: The conceptualization of adaptive negotiations. Journal of Marketing Channels, 21(4), 279-287.

Hemingway, V. (2008). What is an “exclusive agency”? Australian \& New Zealand Journal of Serials Librarianship, 1(3), 55-63.

Karunaratna, A., Johnson, L., \& Rao, C. (2010). The exporter-import agent contract and the influence of cultural dimensions. Journal of Marketing Management, 17(1-2), 137-159.

Kon, M. (1997). Discourse on business opportunities of cross-strait and offshore shipping center. Mainland China Studies, 40(9), 21-41.

Kon, M. (1999). Discourse on how the Taiwanese businessmen keep business secret in the merchanting trade of cross-strait businesses. Journal of the Humanities and Social Sciences, 7(1), 101-140.

Kon, M. (2005). How can Taiwanese exporters avoid payment risks on the trade of cross-strait? Tamsui Oxford Journal of Economics and Business, 13, 81-101.

Kon, M. (2006). How do exporters reduce transport costs? Journal of Chinese Economic Research, 4(1), 81-101.

Kon, M. (2009). Business opportunities from the Chinese mainland opening trading rights to Taiwanese trading firms. Prospect \& Exploration, 7(4), 42-59.

Kon, M., Kung, L., \& Sung, T. (2018). How should China use "B\&R Initiative” to expand its export? Journal of Emerging Issues in Economics, Finance and Banking (JEIEFB), 7(1), 2487-2500.

Lee, M., \& Oh, K. (2012). Buying office as a catalyst in global apparel sourcing: A case study in Korea. Journal of Global Fashion Marketing, 1(4), 250-256.

Li, H., Su, S., \& Lam, H. (2009). On automated e-business negotiations: Goal, policy, strategy, and plans of decision and action. Journal of Organizational Computing and Electronic Commerce, 16(1), 1-29.

Liu, A., \& Sharma, D. (2011). How to attain desired outcomes through channel conflict negotiation. Journal of Marketing Channels, 18(2), 103-121.

Luzzini, D., \& Ronchi, S. (2016). Cinderella purchasing transformation: Linking purchasing status to purchasing practices and business performance. Production Planning \& Control, 27(10), 787-796.

Manrai, A., \& Ajay, M. (2010). The influence of culture in international business negotiations: A new conceptual framework and managerial implications. Journal of Transnational Management, 15(1), 69-100.

Manvi, S., \& Venkataram, P. (2015). Agent based electronic trading. IETE Technical Review, 20(4), 349-359.

Marín, P., \& Sicotte, R. (2003). Exclusive contracts and market power: Evidence from ocean shipping. The Journal of Industrial Economics, 51(2), 193-214.

Matouschek, N., \& Ramezzana, P. (2007). The role of exclusive contracts in facilitating market transactions. The Journal of Industrial Economics, 55(2), 347-371.

Pelecki, K. (2016). International business negotiation strategies based on bargaining power assessment: The case of attracting investments. Journal of Business Economics and Management, 17(6), 882-900.

Shinno, H., Yoshioka H., Marpaung, S., \& Hachiga, S. (2007). Quantitative SWOT analysis on global competitiveness of machine tool industry. Journal of Engineering Design, 17(3), 251-258.

Takahashi, S., \& Matsuo, T. (2012). An efficient trading model for hybrid traders. Applied Artificial Intelligence, 26(8), 715-732.

Turguttopbas, N. (2013). Export credit agency activities in developing countries. The International Trade Journal, 27(3), 281-319. 
Weinstein, A., \& Still, R. (2010). International sales negotiations: The impact of cross-cultural communications. Journal of Global Marketing, 3(3), 73-86.

Wilson, H. (2013). Hotel management contracts: Breach of contract, termination, \& damages. The Journal of Hospitality Financial Management, 7(1), 43-57.

Wong, N., \& Popp, A. (2018). In the best position to reap mutually beneficial results: Sole-agency agreements and the distribution of consumer durables in inter-war Britain. Business History, 60(6), 884-907. 